\title{
American Studies and the New Historicism
}

\author{
María Gema Chocano Díaz \\ C.E.I. Alcalá de Henares, Madrid
}

\begin{abstract}
This essay argues that one major reason American studies has proved resistant to the New Historicism is that its model of pouvoir-savoir, derived from Foucault, works more readily for cultures dominated by centralized power (e.g., Greenblatt's studies of Shakespeare and Renaissance court culture). In the United States, with a tradition of weak and decentralized state power, the relations described by Foucault are more difficult to conceptualize. The other major reason, the essay suggests, is that the "American self" model - a Hegelian notion of "collective consciousness" that dominated American studies from Perry Miller through Bercovitch's Puritans Origins of the American Self - had a certain positive ideological value within American intellectual culture. The essay treats as a representative instance the work of Myra Jehlen, whose American Incarnation was the last major achievement of the "American self" approach, and who is today the leading spirit of the Rutgers "new Americanists."
\end{abstract}

The New Historicism, arguably the most powerful theoretical movement now at work in literary studies in the United States, has for a number of reasons been slow in exerting an influence on the study of American literature. And yet the consequences of the New Historicism in American Studies seem to me extremely significant, not least for scholars in Spanish universities. For one of the effects of the New Historicism has been to demand 
that the "new Americanists," as they are now called in the United States, conceive of American literature and culture in transatlantic terms. So it is, for instance, that the most noteworthy recent contribution to the New Historicism in American Studies, Myra Jehlen's essay on the literature of colonization in the new Cambridge History of American Literature, spends quite as much time analyzing the Historia verdadera de la conquista de la Nueva España of Bernal Díaz del Castillo (1492-1584) as such English sources as Hakluyt's Principle Navigations or Purchas His Pilgrimes.

In this essay, I should like to try briefly to trace the trajectory of the New Historicism as a theoretical movement in the United States, and then to offer an explanation of why it has had a relatively delayed effect on the study of American literature and culture. (As we shall see, an earlier method of approaching American literature and culture, the so-called "American self" approach, played a large role in blocking the influence of the New Historicism when it first arrived in the United States.) Finally, I should like to give a very brief account of one school of the New Historicism, the "new Americanists" movement at Rutgers University in New Jersey, as an example of what I see as being likely to be its most important influence between now and the end of the century.

The New Historicism as such, as is generally known, coincides as a theoretical movement in the United States with Michel Foucault's visits to the University of California at Berkeley in the final years of his life. Before his arrival at Berkeley, Foucault had already become famous as the originator of the theory of pouvoir-savoir, the idea that power and knowledge are simply different versions of a form of "social energy" that gives shape to institutions and relations within a culture. Thus he would argue in The Birth of the Clinic, for instance, that medical knowledge in its modern form became possible when poor patients in the eighteenth-century could be persuaded to "donate" their bodies as physiological systems to physicians and students in return for medical care. Only the new conditions of urbanization, social dislocation, and the anonymity of a mass society provided the experimental subjects - bodies that could be studied and measured and poked and prodded and given medicines on a trial basis, with the results being recorded in the name of "medical science" - that permitted medical knowledge as we now understand it to emerge from the older practices of Galenic or Hippocratic medicine.

In Berkeley, Foucault's main effect was to present a challenge to the then-dominant academic Marxism that had become rooted in west-coast academic culture since the 1960s. For Foucault's notion of pouvoir portrayed even Marxist theory itself as a disguised form of power, which is why the young academics calling themselves the nouveaux philosophes in Paris had been so unrelenting in their critique of the Soviet Union - what we would now call Stalinism - as a Marxist state. (While Foucault himself disclaimed any direct connection with the nouveaux philosophes, they claimed him as a major influence.) For what Foucault's theory said, in essence, is that power relations are ceaselessly at work in every society in disguised forms, very often disguising themselves as theory of knowledge, but always having as its object the subjugation of those who are made "objects of knowledge" or "objects of theoretical understanding." Thus it was possible to see Stalin in the Soviet Union as someone whose career had in a literal sense been "created" by Das Kapital as the textbook of Marxist theory as a form of power-knowledge. 
The effect of Foucault's presence in Berkeley was thus to inspire the first important non-Marxist approach to the study of literature and culture that had been developed there since the 1960s. The leader was Stephen Greenblatt, a scholar of English and European Renaissance literature who in a series of books - Renaissance Self-Fashioning, Shakespearean Negotiations, Marvelous Possessions - carried Foucault's theory of pouvoir-savoir into the study of English Renaissance literature in relation to the society that had produced it. The effect, especially in Greenblatt's work on Shakespeare, was revolutionary. The reason why can be seen from Greenblatt's discussion of Shakespeare's history plays: those works, such as Richard II, Richard III, Henry the Fourth (parts one and two) and Henry the Fifth, in which Shakespeare had portrayed for English people of the Elizabethan age the course of English history from the late middle ages to their own rise to international dominance in the late sixteenth century.

The perception that made Greenblatt's studies revolutionary had to do with a certain notion of the relation between drama and politics, or theaticality and power. For his point was that the monarchy of Elizabeth, though seemingly well established after the political upheaval that had followed the death of her father Henry VIII, was in fact weak in such sources of "actual" power as military strength and national wealth. The illusion that Elizabeth ruled without dissent was, therefore, to a very large degree established by theatricality: by the endless succession of rituals and shows and celebrations that presented the Queen and her court to the nation as the center of national power. This is the context, in Greenblatt's view, in which power itself becomes "theatrical": something that is sustained by a dramatistic show of ceremony and consequence in the eyes of the common people. In portraying English history through actual plays in the actual theater, therefore, Shakespeare was at once sustaining the Elizabethan phenomenon of "power as theatricality" and, in certain subtle ways, simultaneously exposing its unreal or "merely theatrical" nature. So it is that, for Greenblatt's version of the New Historicism, the relation between literature (Shakespeare's history plays) and society (Elizabethan England) becomes a complex "negotiation" over the circulation of power and energy within a given society.

In the United States, led by Greenblatt but with distinguished contributions soon being made by other younger scholars such as Louis Montrose, Charles Ross, and Ronald Levao, the New Historicism thus had its first important effect in the field of Renaissance studies. In subsequent years, it would extend its influence to other fields, first to Victorian studies (Catherine Gallacher, Linda Dowling), then to Eighteenth Century (John Richetti, Adam Potkay), then to medieval studies (Lee Patterson, Susan Crane), and finally to Modern. Yet the one area that was seemingly unaffected was American studies. The paradox was, therefore, that the New Historicism, as a distinctively American theoretical approach, seemed to have few or no consequences for those who actually studied American literature and culture. And that is the way the situation would remain until very recently, when, at last, an explosion of work in the New Historicism has begun to affect the course of American studies in universities across the United States.

One explanation of why American studies was so relatively slow in responding to the theoretical impact of the New Historicism has been offered by Philip Fisher (Harvard University), in an essay surveying recent work in the study of American literature and 
culture from the Civil War to the present. The reason why Foucault's theory of powerknowledge was so inmediately attractive to scholars working the Renaissance, Fisher suggests, is that Renaissance court societies existed in cultures where the embodiment of centralized power in the monarchy was taken for granted: power "radiates outward" from the throne and the court, and it is relatively easy then to map its effects on cultural relations generally (as when Queen Elizabeth would actually go in person to see performances of Shakespeare's plays). The great problem of American society for the New Historicism, then, is that the state power in the United States has historically been weak and decentralized, and, furthermore, not associated with the ownership of land. Thus it is, says Fisher, that the topic of the New Historicism in American studies becomes not power itself but "its weak long-term expectations in a culture in which economic dominance is not located in land - that one genuinely scarce, readily transferable, and not easily variable basis of hegemony" (245).

This is true, I think, and I also think that there is another reason why the New Historicism has had a relatively delayed effect on American studies. This is the dominance within American studies of an "American self" tradition that goes back to Perry Miller's pioneering studies of Puritanism in the 1940s and 1950s, and which has lasted until virtually the present moment. For a discipline that studies American culture in the name of an "American self" that is variously represented in art and literature and politics will not lend itself readily to a theory like Foucault's, which is likely to see such theories as themselves "merely ideological" - a story America tells about itself to justify its own rise to international dominance.

I have taken the phrase "the American self" from the title of a book by Sacvan Bercovitch, the leading contemporary exponent of this approach. In rough terms, it is a Hegelian approach to national culture, with "the American self" functioning as a collective consciousness or psyche in much the way that the Zeitgeist functioned for German romantic nationalism in the early nineteenth century. The great advantage of the approach, as will be evident, is that it permits one to take up all the disparate reflections of culture - literature, cinema, politics, economic developments, customs and traditions - and treat them as the varying expressions of a single unified "self" that is, collectively, the American nation in progress through history. In the United States, which has been compelled to create a national culture from extraordinarily heterogeneous materials inmigrants from a hundred different nations, speaking different languages and holding different religious beliefs, plus local or regional cultures within the United States that are radically different from one another - the attractions of an "American self" approach are perhaps doubly obvious. It is not only a way of organizing a vast heterogeneity into a seeming unit, but it contains a reassuring affirmation of the national motto - e pluribus unum - as well.

The great exponent of the "American self" tradition was Perry Miller of Harvard University, whose researches on the New England Puritans still stand as monuments of thorough scholarship and penetrating cultural analysis. For Miller, who was scarcely concerned with American literature outside of the New England states, it was not the American self but something he called "the Puritan character" that was the most important factor in the subsequent historical development of the United States. Miller stressed, as he 
puts it in Errand into the Wilderness, "the mysticism, the hunger of the soul, the sense of divine emanation in man and nature" (197) in the Puritan character: it was this, he thought, that then left its impress on the American national character in the century to come. For though there were already middle and southern colonies in the seventeenth century, and though Americans would eventually conquer a vast continent in the years following the American Revolution, Miller thought that the whole process of national development took its guiding spirit from the Puritan sense of divine mission: the "city on a hill" that John Winthrop had said it was the task of the original Pilgrim settlers to establish in New England. The idea of an America that was energetic, youthful, innocent, and driven by moral purpose was, Miller thought, a direct legacy of the Puritan fathers, something that lingered long after New England Puritanism itself had faded from memory.

In the last twenty years, the exponents of "the American self" approach have simply adopted Miller's hypothesis of a single collective American mind or psyche and projected it onto the nation as a whole. America on this account simply becomes a continent-wide fulfillment of the original "errand into the wilderness" that had led the original Pilgrims to abandon an old, corrupt Europe and set out to establish a new social order in the New World. The single most influential book written in this mode in recent years is Sacvan Bercovitch's The Puritan Origins of the American Self. (Bercovitch now teaches at Harvard, where Miller was a professor throughout his career.) Here is a typical passage from Bercovitch's book. It is less important, I want to suggest, for its argument or thesis than for the way it keeps in view a single "collective American psyche" as its explanatory model:

The colonial Puritan myth linked self- and social assertion in a way that lent special support to the American Way. From Mather through Emerson, auto-American-biography served rhetorically to resolve the conflicts inherent in the very meaning of "freeenterprise": spiritual versus material freedom, private versus corporate enterprise, the cultural "idea," expressed by the country's "purest minds," versus the cultural fact, embodied in a vast economic-political undertaking. The same Puritan myth, differently adapted, encouraged Edwards to equate conversion, national commerce, and the treasures of a renovated earth, Franklin to record his rise to wealth as a moral vindication of the new nation, Cooper to submerge the historical drama of the frontier in the heroics of American nature, Thoreau to declare self-reliance an economic model of "the only true America," Horatio Alger to extol conformity as an act of supreme individualism, and Melville, in Moby-Dick, to create an epic hero who represents in extremis both the claims of Romantic isolation and the thrust of industrial capitalism. (186)

One sees, I think, how powerful an obstacle this represents to the New Historicism with its stress on the interchanges between power and knowledge. For when one takes as explanatory model the notion of a single collective national psyche, as Bercovitch is so clearly doing here, one has a logic of homogeneity that is almost certain to dissolve all notions of heterogeneity, conflict, dialogue, or contestations of cultural power. The same is true of the last really distinguished work in the "American self' mode, Myra Jehlen's American Incarnation. Its argument is, in very brief terms, that an identification of the American continent (land) with Edenic innocence then allowed Americans to see 
themselves as existing outside history and innocent of $\sin$ or guilt: "Identity with the natural universe generalized the individual into Man: it did the work of history and society at no cost to him, nationalizing and even moralizing him without (apparently) limiting him. Thus the totally separate individual of American mythology, the Adamic man alone in a vacant wilderness, builds his own world (according to the myth) without having to expend himself in the construction of society." (14)

As we shall see in a moment, Jehlen is a symbolic figure for the development of the New Historicism in American studies, for after American Incarnation she would renounce the "American self" approach and enter wholeheartedly into the project of studying America from the angle of vision suggested by the New Historicism, and in particular by Greenblatt's studies of English Renaissance culture. But before Jehlen's "conversion" took place there appeared in the United States the first really important work of New Historicism scholarship in the field of American sudies: Walter Benn Michaels's The Gold Standard and the Logic of Naturalism. Michaels, who had been a junior faculty member at Berkeley at the time when senior faculty members like Greenblatt were coming under the influence of Foucault's cultural theories, was the first to adapt the Foucauldian notion of pouvoir-savoir to the situation of an American society in which "culture" as such was always dialogic and heterogeneous and power was weak and decentralized in comparison with region and local tradition.

The argument of The Gold Standard and the Logic of Naturalism is subtle and complex, far too much so for any attempt to summarize it in an essay like the present one. The gist is this: in the controversy over the Gold Standard that dominated American political controversy at the end of the nineteenth century, with the eastern states, by and large, in favor of maintaining the gold standard as a national monetary unit, and the westerners, led by William Jennings Bryan, in favor of "bimetallism" - gold and silver serving equally as the national currency, with an increase of national prosperity then favoring the silver-producing states of the West - Michaels sees a logic similar to that of literary Naturalism, which during the same period provided the major controversy in American literature, with such authors as Mark Twain and William Dean Howells arguing in favor of a literature that portrayed "real life" in grimly naturalistic terms: the lives of ordinary Americans, amidst poverty and crime and violence, as they really existed, with no attempt at escapism or ornamentation. What gives the two episodes a logic in commom, Michaels argues, is the growing fear that American life has become unmmored or ungrounded in The Real: as currency needs gold behind it to give ir "real value," literature needs to incorporate the elements of "real life" to give it literary truth, thus restoring stability and ballast to a national life that to many late nineteenth-century American intellectuals (Henry Adams, Henry James, T.S. Eliot) seemed to be a vacuum in which mere endless economic striving had taken the place of culture as such.

The success of Michaels's book then prepared the way for Myra Jehlen's much discussed shift to the New Historicism. Jehlen's work is extraordinarily important to an understanding of recent developments in American studies, for - as mentioned in the first paragraph of this essay - she has today become one of most distinguished exponents of the New Historicism in the United States. The trajectory of her career, from the last great expression of the "American self" approach in American Incarnation to her renunciation 
of that approach in her introduction to Ideology and Classic American Literature, a volume she edited with Bercovitch, to her more recent "Literature of Colonization" essay in the Cambridge History, a paramount example of the New Historicism as its best, then summarizes an entire intellectual movement as it is today altering the nature of American studies.

With Jehlen's intellectual conversion came a shift in instituional affiliations. As the time she wrote American Incarnation, Jehlen occupied an endowed chair at the University of Pennsylvania. Her shift to the New Historicism was then signalled by her move to Rutgers University in New Jersey, where the most important senior Americanist in the United States (Richard Poirier) and two important younger Americanists (William Dowling and Michael Warner) were doind pioneering work in the New Historicism. Today, the Rutgers "new Americanist" project is perhaps the single most cohesive version of the New Historicism in the United States, with Poirier's quaterly journal Raritan as its leading organ of publication, and the work of the Rutgers Americanists exemplifying, in its various modalities, the possibilities that younger scholars in universities across the country have begun to develop in their studies.

Although he is in many ways the spiritual godfather of the Rutgers "new Americanist" project, Richard Poirier is himself not a New Historicist. His importance to the project lies in the way his recent work - especially Poetry and Pragmatism - emphasized the possibilities of a fruitful or generative relationship between American studies and various modalities of continental theory, especially that of middle-period Foucault. For Poirier's recent work, like that of Foucault in the period just before The History of Sexuality, has been preoccupied with the way literature operates not simply as a mirror of social reality but as an intervention in that reality: an attempt to alter the way a society conceives of its own cultural possibilities. Poirier's greatest work as an Americanist has been devoted to Ralph Waldo Emerson, and his emphasis has always been on Emerson as a prophetic writer, someone who wished to alter the very conditions of American thought and social existence through his writing. This is literature as "power" in something like Greenblatt's sense, and, if not itself New Historicist, represents a perspective deeply congenial to a New Historicist way of seeing American history and society. In addition, as mentioned above, Poirier is the founder and editor of Raritan, today the most influential intellectual quarterly in the United States. Under his editorship, its pages have consistently been open to distinguished work in the New Historicist mode.

In quite a different key is the work of Michael Warner, whose rise to a national visibility as an Americanist - he received his $\mathrm{PhD}$ only eight years ago - has been very nearly spectacular. The source of the excitement is Warner's book The Letters of the Republic, in which he develops not only a new theory of early American lierature but, in effect, a new theory of the American Revolution. The heart of Warner's theory is the Habermasian "public sphere": the idea, originating with Jurgen Habermas, that the spread of print technology and literacy in europe between the Renaissance and the eighteenth century brought about a shift or alteration at the deepest level of political and intellectual culture, such that the invisible force of opinion publique - the imaginary presence of a large body of informed readers - begins to alter the way monarchs and statesmen conceive of their own relations to governance and power. To greatly oversimplify 
Habermas's account of the public sphere, one could say that opinion publique on his account becomes an invisible "third force" in national and international politics between the seventeenth and eighteenth centuries, so that politicians and courtiers no longer look only towards the throne in gauging the consequences of their decisions and actions, but towards an invisible "public" which will judge both them and the monarch on the morality and reasonableness of their actions.

In The Letters of the Republic, Warner accepts the Habermasian account in its main outlines, but makes two important alterations. First, as he points out, a special application of Habermasian theory is needed in the American case, for the United States was the first polity in history to come into existence as a polity under the conditions of opinion publique and the public sphere. Thus Warner is able to explain the enormous significance of print and print culture in the period of the Revolution and early republic: the extraordinary impact of a pamphlet like Thomas Paine's Common Sense, for instance, which galvanized American resistance to Britain and, almost in a matter of weeks, turned the tide of public sentiment in favor of complete independence (before Paine's pamphlet, most Americans had been hoping for some sort of peaceful settlement with the mother country). In the same way, Warner explains the importance of the Declaration of Independence and the U.S. Constitution (the first written national constitution) as consequences of the public sphere and print culture. It is the explanation, as well, he argues, of the symbolic importance of Benjamin Franklin, who was himself a printer, and who became both wealthy and famous due to the printing press (the basis of his personal fortune was Poor Richard's Almanac, owned by nearly every household in the American colonies). The United States was, on Warner's account, a nation brought into existence by the printing press and the new culture of print that Habermas calls the public sphere.

Yet Warner's argument goes beyond that of Habermas, making a further point that is never made in Habermas's The Structural Transformation of the Public Sphere. For on Habermas's account, the development of a separate sphere of opinion publique is simply a consequence of the advance of printing technology: when there are enough printing presses, and enough new readers, something changes in the political and intellectual culture of Europe. Warner's argument brilliantly explains what changes: it is that people begin to read in a new way, looking at the printed press with a simultaneous awareness that the same page is available to thousands or millions of other readers on just the same terms. On Warner's account, in short, the "public sphere" comes into existence only when the interaction between the reader and the printed page alters in a radical way: "By 'normally impersonal,' I mean that the reader does not simply imagine him- or herself receiving a direct communication or hearing the voice of the author. He or she now also incorporates into the meaning of the printed object an awareness of the potentially limitless others who may also be reading. For that reasons, it becomes possible to imagine oneself, in the act of reading, becoming part of an arena of the national people that cannot be realized except through such mediating imaginings" (xiii).

The other early example of the Rutgers "new Americanist" approach was William C. Dowling's Poetry and Ideology in Revolutionary Connecticut, a study of a previouslyobscure group of early American poets (Timothy Dwight, Joel Barlow, David Humphreys, John Trumbull) known as "the Connecticut Wits." To the extent that they had commanded 
the attention of literary historians, the Connecticut Wits had been studied mainly as a matter of antiquarian interest, as "belated" Augustan poets - they wrote in the style of such English poets as Dryden and Pope and Cowper, who had been active two generations before - writing imitative verse in a young America that had no literary traditions of its own. The point of Dowling's reinterpretation is that such poets as Dwight and Trumbull must indeed be seen as carrying on the tradition of the English Augustan poets, but that the tradition they were carrying on saw poetry as a means of symbolically intervening in the historical development of one's culture or nation.

The widespread influence of Dowling's Poetry and Ideology owes a great deal to the recent interpretation, in English literature, of English Augustan poetry, where such writers as Pope and Swift and Gay are now understood as having fought a lifelong battle against the "corruption" symbolized for them by Sir Robert Walpole - prime minister under England's new Hanoverian sovereigns - and a money or market society that, during the course of the eighteenth century, would erode English traditions and customs and establish wealth, rather than virtue or talent, as the basis of political power. What is crucial to understanding the Connecticut Wits, writes Dowling "is the idea of poetry involved in the Augustan warfare against corruption and social decline, a real sense that individuals and societies are constituted in an essential way by systems of ideas or perceptions, and that literature may intervene in this process in a decisive way... Reading the poetry of Dryden or Pope or Trumbull or Dwight with genuine comprehension involves learning to live again in a world where poems are symbolic interventions with enormous consequences in the domain of the real." (xv).

As the influence of Warner's Letters of the Republic no doubt owes a great deal to the way in which its argument extends that of Habermas, the influence of Dowling's study is almost certainly due to the way his argument extends that made by J.G.A. Pocock in The Machiavellian Moment, who had argued that the great archetype for political controversy since the time of Horace and Livy and Virgil had centered on a single "myth of the lost republic": in Rome, in England, and then in the late-eighteenth-century America, a time of virtus in which the thought of the citizens is for the community as a whole, which then gives way to a time of "corruption" - the selfish indulgence of private or personal aims at the expense of the community - and brings about the downfall of civilization. (Pocock's title takes Machiavelli as its central figure because Machiavelli's commentaries on Livy made once again available to European politics the older Polybian language of virtue, corruption, and decline.) On Dowling's interpretation, the young American republic becomes a version of the early Roman republic in its simplicity and virtue, and the task of poetry is to warn it against the degeneration into corruption and decline associated with the older civilizations of the European world.

As numerous reviewers have noted, the common denominator in the Rugers "new Americanist" project as represented by Poirier, Warner, and Dowling, has been its focus on transatlantic relations - its insistence, as Dowling puts it in Poetry and Ideology "that English and European and American writers be seen as inhabiting a single trasatlantic universe of thought" (xvii). This had been the theme of Poirier's concentration on such works as Emerson's English Traits. It lies behind Warner's conception of the Habermasian public sphere as involving a new epistemology of reading common to Europe and the 
American colonies, and it is central to Dowling's portrayal of the Connecticut poets as the literary Augustans of the new American republic, carrying on the literary mode of Dryden and Pope and Johson and Cowper on their own side of the Atlantic under closely related cultural conditions. No single feature, perhaps, more markedly signals the difference between the older "American self" approach, which had always treated the United States in isolation as a world cut off by geography and history from Europe, and the New Historicism, which sees "America" as nothing other than a European idea that put down roots on the continent discovered by European voyages and explorers in the late fifteenth century.

This is the theme of Myra Jehlen's most recent work. For Jehlen, as a survey of her previous work suggests, was almost certainly drawn to the Rutgers "new Americanist" project by its trasatlantic focus. The subject of her recent work might even be described as being "America" as a creation of European ideas, attitudes, expectations, her point being that "America" existed as an element in European imagination long before Columbus and his men went ashore in the New World (much as the notion of interplanetary travel existed in science fiction and the popular imagination long before the first astronauts set foot on the moon). "The Literature of Colonization," Jehlen's important contribution to the first volume of the newly-published Cambridge Literary History of America, is in this sense an exploration of "the New World" itself as, first of all, an imaginary entity, something existing in the cultural imagination long before it came to exist as a physical or social fact.

Jehlen's essay gives pride of place, as might be expected, to accounts of travels and exploration written in English, such works as Thomas Harriot's Brief and True Report of Virginia, Captain John Smith's record of his Virginia experiences, Hakluyt's Principle Navigations and Purchas's continuation. For as historical circumstance would have it, the northern continent of the two major landmasses constituting the new World would be settled by English speakers, with consequences for global politics that retain their importance in our own century. Yet Jehlen gives, as well, a great deal of attention to the voyages of Columbus - her detailed comparison of his Diario with the Travels written by Marco Polo two centuries before, as illustrating the radical differences between the latemedieval and emergent Renaissancve world-view, is a brilliant piece of literary and anthropologial exegesis - and to the accounts left by such Spanish explorers as Bernal Díaz del Castillo and Cabeza de Vaca. The emphasis of Jehlen's analysis, throughout, is on the way written discouse - the pronouncements of colonial administrations, the tales of travellers, the accounts written to attract new settlers - imposed its categories on the New World, so that "America" would become, in the end, an entity as much constructed out of thought and language as a physical space inhabited by European settlers.

The sort of focus one observes in the Rutgers "new Americanist" project is, one is entitled to suppose, the direction that will be taken by younger scholars in other universities as they become conversant with the methods of New Historicist scholarship. The grand effect, as one already sees, is to dissolve "America" as it existed for American studies - that unified, homogeneous, collective consciousness once so confidently referred to as an "American self" - into a plurality of competing discourses and cultural systems, a "new" society or culture created through the reworking of European materials in an 
endless process of separation and recombination. The unexpected effect of the New Historicism in American studies has thus been to bring to light an America that has all along existed as a distant reflection in the mirror of European civilization, that Old World that stepped ashore on the new continent with Columbus and the men who rowed him ashore. A subsequent effect, we may equally suppose, will be that European scholars and not least scholars in Spain, the civilization in which the idea of "America" assumed its earliest shape and name - will soon begin to recognize the reflection of their own culture in the mirror of America held up by he New Historicism.

\section{Works Cited}

Bercovitch, Sacvan. The Cambridge History of American Literature. Volume One: 1590-1820. Cambridge, England: Cambridge University Press.

Bercovitch, Sacvan. The Puritan Origins of the American Self. New Haven, Conn.: Yale University Press, 1975.

Bercovitch, Sacvan, and Jehlen, Myra. Ideology and Classic American Literature. Cambridge, England: Cambridge University Press, 1986.

Dowling, William C. Poetry and Ideology in Revolutionary Connecticut. Athens, Georgia: University of Georgia Press, 1990.

Fisher, Philip. "American Literary and Cultural Studies since the Civil War." In Greenblatt and Gunn.

Greenblatt, Stephen, and Gunn, Giles, eds. Redrawing the Boundaries: The Transformation of English and American Literary Studies. New York: Modern Language Association of America, 1992.

Jehlen, Myra. American Incarnation: the Individual, the Nation, and the Continent. Cambridge, Massachusetts: Harvard University Press, 1986.

Jehlen, Myra. "The Literature of Colonization." In Bercovitch, Cambridge History.

Michaels, Walter. The Gold Standard and the Logic of Naturalism. Berkeley: University of California Press, 1987.

Miller, Perry, and Johnson, Thomas H., eds. The Puritans. New York, Harper and Row, 1963.

Miller, Perry. Errand into the Wilderness. New York: Harper and Row, 1956.

Veeder, H. Aram, ed. The New Historicism. London: Routledge, 1989.

Warner, Michael. The Letters of the Republic. Cambridge, Massachusetts: Harvard University Press, 1990. 